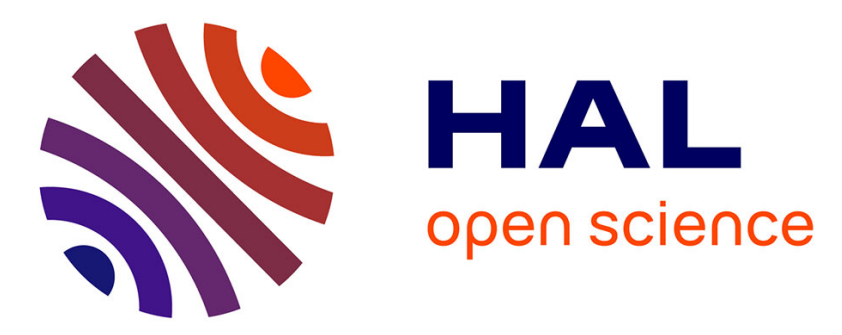

\title{
The use of airborne remote sensing for benthic cartography: Advantages and reliability
}

\author{
V. Pasqualini, C. Pergent, Catherine Fernandez, G. Pergent
}

\section{To cite this version:}

V. Pasqualini, C. Pergent, Catherine Fernandez, G. Pergent. The use of airborne remote sensing for benthic cartography: Advantages and reliability. International Journal of Remote Sensing, 1997, 18 (5), pp.1167 - 1177. 10.1080/014311697218638 . hal-01768676

\section{HAL Id: hal-01768676 https://hal.science/hal-01768676}

Submitted on 17 Apr 2018

HAL is a multi-disciplinary open access archive for the deposit and dissemination of scientific research documents, whether they are published or not. The documents may come from teaching and research institutions in France or abroad, or from public or private research centers.
L'archive ouverte pluridisciplinaire HAL, est destinée au dépôt et à la diffusion de documents scientifiques de niveau recherche, publiés ou non, émanant des établissements d'enseignement et de recherche français ou étrangers, des laboratoires publics ou privés. 


\title{
The use of airborne remote sensing for benthic cartography: advantages and reliability
}

\author{
V. PASQUALINI, C. PERGENT-MARTINI, C. FERNANDEZ and \\ G. PERGENT \\ Equipe 'Ecosystèmes Littoraux', Université de Corse, \\ Faculté des Sciences et Techniques, BP 52, 20250 Corte, France
}

(Received 14 April 1996; in final form 23 July 1996)

\begin{abstract}
Airborne remote sensing is a useful tool for the production of biocenosis maps. The use of an image processing system, integrating bathymetric data, makes it possible to considerably refine the charting, through a layer of water of variable thickness and quality. Other limiting factors may have an impact on the quality of results. The identification of these factors makes it possible to propose a scale of reliability. Four examples of aerial teledetection surveys provide the basis for (i) assessing the reliability of the maps, (ii) determining the reasons for this variation in reliability, and (iii) using the scale as a means for assessing the reliability of a given map. The factors used are such that the reliability scale could subsequently be applied to the cartography of other marine assemblages.
\end{abstract}

\section{Introduction}

Mediterranean island coastal environments present specific characteristics, with a relatively extensive coastline, that is often dotted with lagoons. The Mediterranean islands are blessed with an exceptionally rich natural patrimony (e.g., endemic species), but have suffered from deterioration that is aggravated by the fact of being an island (geographical isolation, limited resources, demographic patterns, summer tourist influx, waste elimination and purification; Kerdoun 1992). Nevertheless, several of these islands may be considered as privileged environments with regard to various anthropic pressures. Efficient management of island coastal areas (development, valorization, protection) requires detailed knowledge of the environment, and this is rarely available. Corsica is confronted with the same problems as other Mediterranean islands (less of 10 per cent of its coast has been surveyed for biocenosis cartography; Pergent et al. 1995). The Corsican authorities are attempting to implement a properly coordinated management plan in order to ensure lasting development of the Mediterranean environment.

The first stage of any environmental management plan involves recording the existing situation by mapping the main benthic assemblages and bottom types. The initial survey of an area for which there is little available data involves the use of small-scale cartographical techniques (Pergent et al. 1995). Aerial and satellite teledetection is a tool that is particularly well-suited to this type of survey (Belsher et al. 1988, Meinesz et al. 1988, 1991, Kirkman 1990). Image processing techniques make it possible to chart the various benthic assemblages and bottom types rapidly and accurately (Kelly 1980, Manière and Jaubert 1985). Aerial photography has the advantage of offering a degree of resolution (size of the pixel) that can be modulated according to the results required (Walker 1989), and good identification of the 
different benthic assemblages and bottom types down to a depth of about $20 \mathrm{~m}$. However, one of the major problems of image processing when applied to the marine environment is the impact of the layer of water (of variable quality and thickness). This can result in variations of the spectral signature for the same benthic assemblage or bottom type (Pirazzoli 1982, Belsher et al. 1988). In order to lessen the impact of this artefact, a special processing procedure has been developed.

Other parameters, such as the complexity of the area studied in term of the topography, the bathymetric range and the turbidity of the water, can also alter the perception of the data and consequently the reliability of the result. It is thus important to dispose of suitable criteria for assessing this reliability of the maps. While there has already been some research on this (Courboules et al. 1988, Fergusson et al. 1993, Morgan et al. 1993), there is still no standard assessment scale. A standard scale of reliability, taking into account the various factors that may affect the quality of the results, is therefore proposed.

\section{Materials and methods}

Surveys have been carried out in four areas along the Corsican coast (figure 1). The main marine benthic assemblages and bottom types taken into account are, where they occur:

(i) soft sediments (silt and/or sand),

(ii) hard substrat (photophilous algae on rock and/or pebbles),

(iii) seagrass beds (Posidonia oceanica (L.) Delile or mixed bed of Cymodoea nodosa (Ucria) Ascherson and Zostera noltii Hornemann). About the seagrass beds of Posidonia oceanica, an endemic phanerogam of the Mediterranean sea, we distinguish between continuous meadow presenting coverage greater than 50 per cent, and a patchy seagrass or mosaic seagrass bed (on matte, rock or sand).

Image processing is based on $1 / 6500$ to $1 / 20000$ scale aerial colour photographs taken in June 1994, following the technical specifications described by Lefevre et al. (1984). The final spatial resolution of the scanned photographs varies from 1 to $5 \mathrm{~m}$, depending on the image studied. Field data was collected (i) by random localisation using a GPS positioning system with an accuracy of approximately $20 \mathrm{~m}$ (Global Positioning System PRONAV $100^{\circledR}$ ), (ii) by the transect method (Meinesz et al. 1981). Digitisation of the aerial photographs was carried out using a colour scanner (Canon CLC 10 piloted by an IBM compatible Pentium 100 PC) using IMAGE-IN SCAN \& PAINT software (Image $\operatorname{In}^{\circledR}$ ) in 16.8 million colours.

After digitisation, each pixel of the image (elementary point) corresponds to a vector of properties, formed of reflectances for each primary colour in the visible spectrum: red, green and blue $(R, G, B)$ or coloured plane. All the following processing procedures are processed from three planes $(R, G, B)$, using the software MULTISCOPE (version 2.3 of the company Matra Cap System $\left.{ }^{(}\right)$). Geometrical rectification is carried out on each image to eliminate distortions resulting from the photographic process. A polynomial model of degree 1 is established from coordinated reference points, taken on the working image and on reference maps (e.g., cadastral surveys, Institut Géographique National maps-IGN). This model is then applied to each point of the working image (Meaille et al. 1988). Elimination of the terrestrial area is achieved from the original image, by delimiting by closed polygons the land-sea boundary. The dynamics are adjusted by enhancing the 


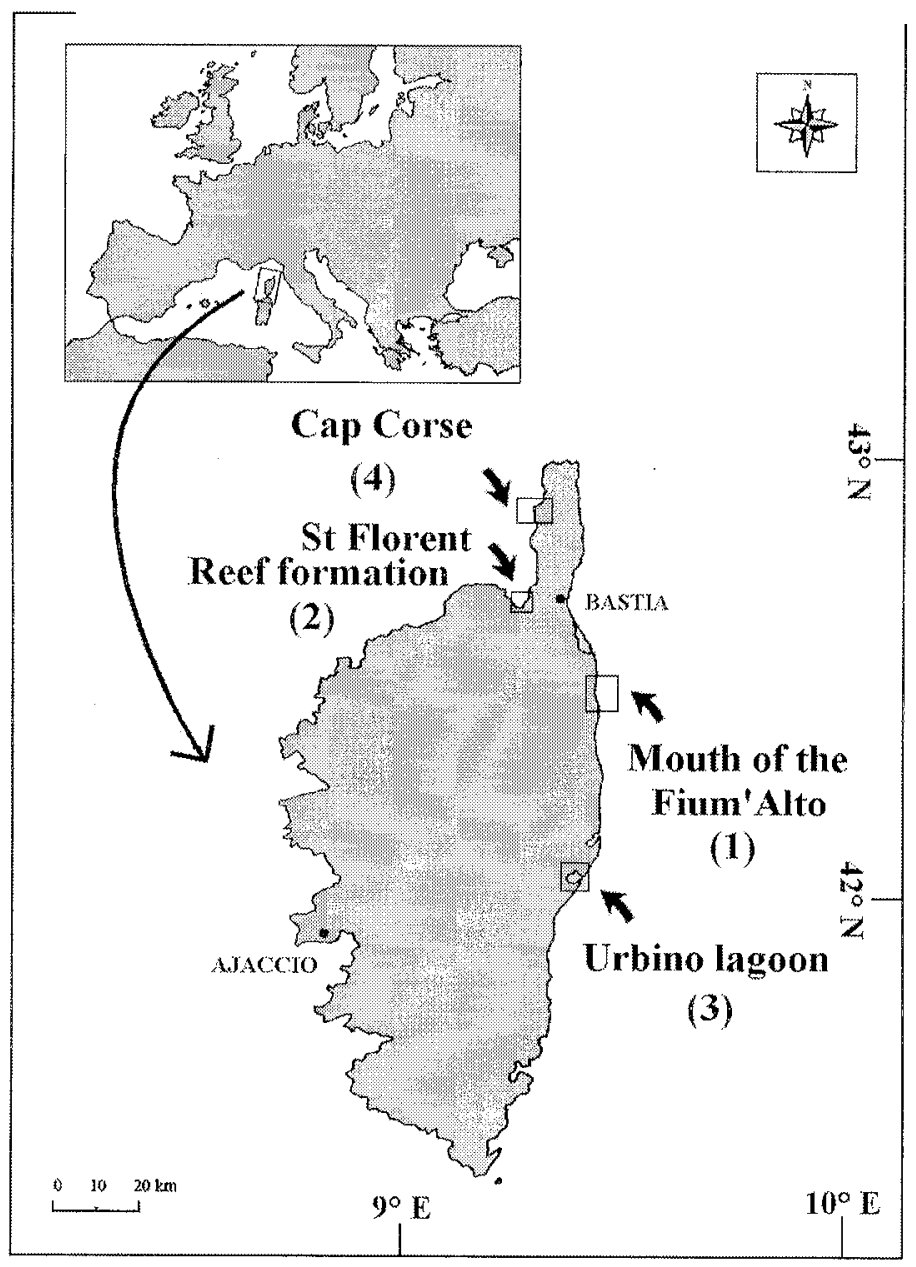

Figure 1. Geographical location of the study site.

contrast of the image, and thus gaining in precision and clarity. Principal Component Analysis (PCA) is a statistical method that consists in presenting in graphic form the maximum of information by transforming the radiometric values of two or several planes that are strongly inter-correlated into new planes in which the information is reorganised in hierarchical fashion (Philipeau 1986). This technique is applied to the blue and green planes, since between these two planes there is a strong coefficient of correlation (about 0.90 ). The first component or plane $\mathrm{P} 1$, resulting from the PCA and expressing a major part of the total variance, is applied to the initial blue and red planes to form a coloured composition, in order to optimise the differentiation of surface assemblages down to a depth of about 20 . The coloured composition is used to position the reference polygons, assumed to contain pixels belonging to the same assemblages or bottom types (Courboules and Manière 1992). The positioning of the polygons is based on in situ observations. Classification supervised by generalised hypercube is based on the fuzzy entity theory, defined by the histograms of the classes in each of these planes. This classification is carried out on the coloured composition (Manière et al. 1994). Homogenization allows the 
elimination of isolated points. The use of a non-linear filter means that on an elementary square of 3 by 3 pixels the isolated pixels can be identified and attributed the values of the surrounding pixels. The processed images are assembled in such a way as to obtain a mosaic covering the whole of the surveyed area. A second geometrical rectification is carried out, with a second order polynomial, on the terminal mosaic in order to superimpose the whole sector on the reference map.

\section{Results and discussion}

Processing of an aerial photographic survey of an area situated along the east coast of Corsica up to the mouth of the Fium' Alto, revealed a number of errors of interpretation in relation to the field data (figure $2(a)$ ). These errors are related to the fact that a given assemblage can present different spectral signatures according to the depth (Belsher et al. 1988). In order to reduce this bias to a minimum, a special processing system has been developed. It consists in carrying out a specific processing procedure for each depth range $(0$ to $5 \mathrm{~m}, 5$ to $10 \mathrm{~m}$ and 10 to $20 \mathrm{~m})$. The reason for the choice of the 5,10 and $20 \mathrm{~m}$ isobaths is that these are the only ones shown on the IGN maps. They make it possible to easily divide the image according to the depth. The image processing is carried out initially, between 0 and $5 \mathrm{~m}$ depth with positioning of reference polygons for each of population and bottom type that occurs, solely within this bathymetric range. An identical processing procedure is carried out between 5 and $10 \mathrm{~m}$ and finally between 10 and $20 \mathrm{~m}$. The results obtained are then superimposed to provide a single image (figure 2(b)). Comparison of these results with the field data confirms the advantages of this processing procedure.

In terms of reliability, the end result may be strongly influenced by the processing procedure used. In addition, it seems worthwhile to assess the impact of other factors, such as the complexity, the nature and the quality of the site studied, or the quality of the photograph, on the results. Detailed identification of these factors (table 1 ) is a vital stage in the establishment of a reliability assessment scale.

For example, a steeply sloping bottom, a deep water layer or a high degree of turbidity may make visualisation of the various assemblages and the sea bed in between difficult. Similarly, as has been stressed by Lefevre et al. (1984), the meteorological and technical conditions (e.g., nature of vector, scale, nature and format of the film, focal, filters...) under which the photographs were taken would appear to be a determining factor with regard to the accuracy and reliability of the results (table 1).

During digitisation, the choice of pixel size (ranging from some tens of centimetres to more than $10 \mathrm{~m}$ ) is based on the purpose of the study and the surface area of the site under investigation. Nevertheless, it is necessary to choose a photograph of a scale that is compatible with the resolution desired (Lefevre et al. 1984). Thus the pixel size largely determines the accuracy of the results (table 1).

The accuracy of the geometrical rectification depends both on the number of reference points, that has to be sufficiently large to allow statistical treatment, and their distribution over the whole of the image under consideration. In an aerial photograph, there is in fact uniform geographical distortion that increases progressively in every direction in correlation with the distance from the centre of the photography. Optimum rectification necessitates a distribution of reference points in all four directions on the image. The precision of the referential must also be taken into account, to the extent that the choice of a large scale referential provides a more accurate localisation of the reference points (table 1). 


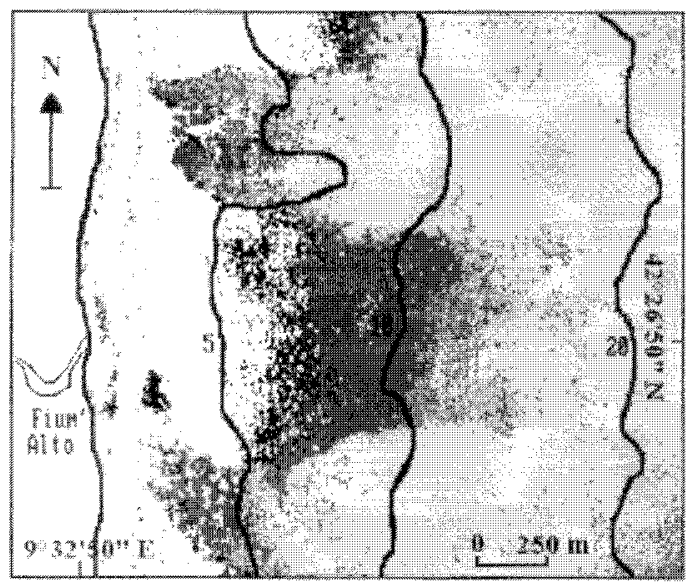

(a)

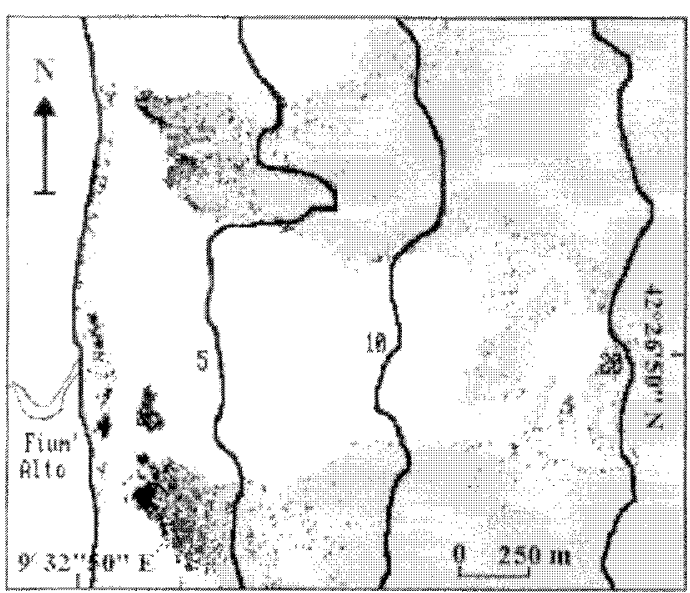

(b)

Patchy seagrass bed

Photophilous algae on rock

$\square$ Continuous seagrass bed

Sand

Land

Figure 2. Maps of the main benthic assemblages and bottom types at the mouth of the Fium'Alto, between 0 to $20 \mathrm{~m}$ depth. (a): General image processing; (b): Image processing by depth range.

The validation of the data resulting from photography involves identification by scuba diving (field data) and/or reference to bibliographical data. The reliability of the bibliographical data is estimated on the basis of the scale of Meaille et al. (1988). Only data credited with a value greater than 16 on this scale (good reliability or total reliability) are considered a field data. The number of items of field data required (survey surface area) depends on the size of the area under investigation, the degree of accuracy required and the distribution of the assemblages and bottom types. The delimitation of reference polygons allows the field data to be integrated into the 
Table 1. Main factors influencing the quality of image processing of aerial photographs and scale of reliability $(<:$ less than; $>:$ more than;

*: the reference point factor is subdivided into two sub-parameters, each with a weighting coefficient of 0.5 ).

\begin{tabular}{|c|c|c|c|c|}
\hline \multirow[b]{2}{*}{ Factors } & \multicolumn{4}{|c|}{ Scale of reliability } \\
\hline & 3 points & 2 points & 1 point & 0 point \\
\hline \multicolumn{5}{|l|}{ Survey site } \\
\hline Topography: slope & Slight and even & Strong and even & Slight and uneven & Strong and uneven \\
\hline Bathymetric range & 0 to $5 \mathrm{~m}$ & 0 to $10 \mathrm{~m}$ & 0 to $20 \mathrm{~m}$ & 0 to below $20 \mathrm{~m}$ \\
\hline $\begin{array}{l}\text { Water turbidity: visualization of assemblages } \\
\text { and bottom types }\end{array}$ & $\begin{array}{l}100 \% \text { of the depth } \\
\text { range studied }\end{array}$ & $\begin{array}{l}75 \% \text { of the depth } \\
\text { range studied }\end{array}$ & $\begin{array}{l}50 \% \text { of the depth } \\
\text { range studied }\end{array}$ & $\begin{array}{l}\text { Less of } 50 \% \text { of the } \\
\text { depth range studied }\end{array}$ \\
\hline Nature of assemblages and bottom types & Very different & Different & Similar & Very similar \\
\hline \multicolumn{5}{|l|}{ Aerial photography } \\
\hline Surface effects: specular reflexion, wave plane & No surface effect & $\begin{array}{l}\text { Surface effect at a } \\
\text { distance from the site }\end{array}$ & $\begin{array}{l}\text { Surface effect close } \\
\text { to the site }\end{array}$ & Surface effect at site \\
\hline \multicolumn{5}{|l|}{ Scanning } \\
\hline Pixel size & Pixel $\leqslant 2 \mathrm{~m}$ & $2 \mathrm{~m}<$ Pixel $\leqslant 5 \mathrm{~m}$ & $5 \mathrm{~m}<$ Pixel $\leqslant 10 \mathrm{~m}$ & Pixel $>10 \mathrm{~m}$ \\
\hline \multicolumn{5}{|l|}{ Geometrical rectification } \\
\hline *Reference points: number & Number $\geqslant 20$ & $20>$ Number $\geqslant 10$ & $10>$ Number $\geqslant 4$ & Number $<4$ \\
\hline distribution & In 4 directions & In 3 directions & In 2 directions & In 1 direction \\
\hline Referentiel scale/Image scale & Referentiel > image & Referentiel = image & Referentiel < image & Referentiel «image \\
\hline \multicolumn{5}{|l|}{ Field data } \\
\hline Area covered by field data/study site area & $\begin{array}{l}\text { Area } \geqslant 10 \% \text { of the } \\
\text { study site area }\end{array}$ & $\begin{array}{l}10 \%>\text { Area } \geqslant 5 \% \text { of } \\
\text { the study site area }\end{array}$ & $\begin{array}{l}5 \%>\text { Area } \geqslant 1 \% \text { of } \\
\text { the study site area }\end{array}$ & $\begin{array}{l}\text { Area }<1 \% \text { of the } \\
\text { study site area }\end{array}$ \\
\hline \multicolumn{5}{|l|}{ Classification } \\
\hline $\begin{array}{l}\text { Number of polygons by assemblages and } \\
\text { bottom types }\end{array}$ & Number $>30$ & $30 \geqslant$ Number $>15$ & $15 \geqslant$ Number $>5$ & Number $<5$ \\
\hline Sum & 33 & - & - & - \\
\hline
\end{tabular}




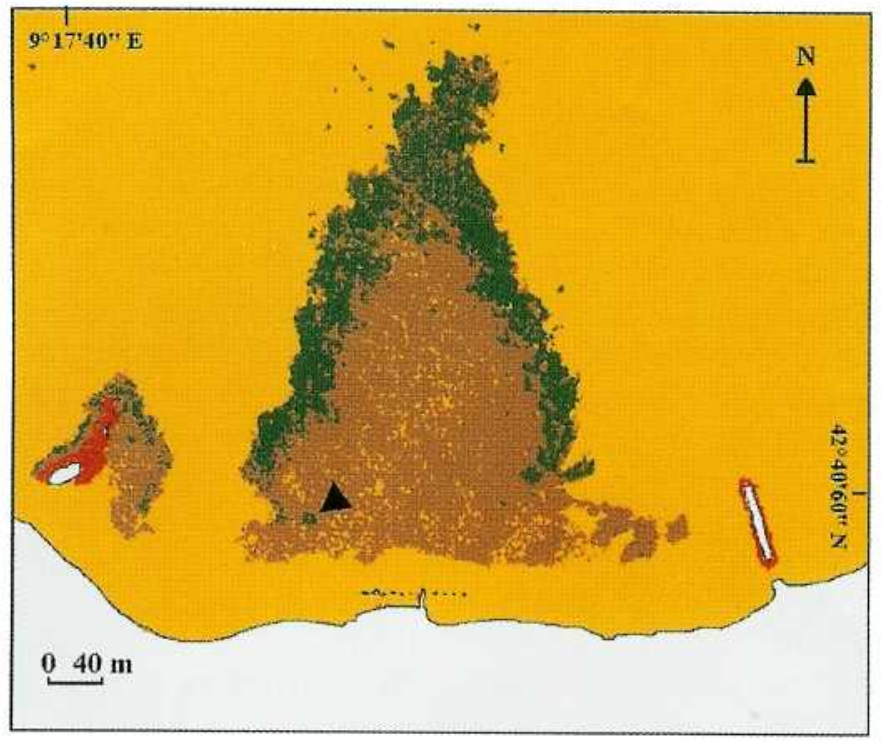

Patchy seagrass bed

Photophilous algae on rock

Continuous seagrass bed

Sand

Land

Figure 3. Map of the main benthic assemblages and bottom types in the vicinity of St. Florent reef formation (Corsica). ( $\mathbf{\nabla}$ : Micro-atoll)

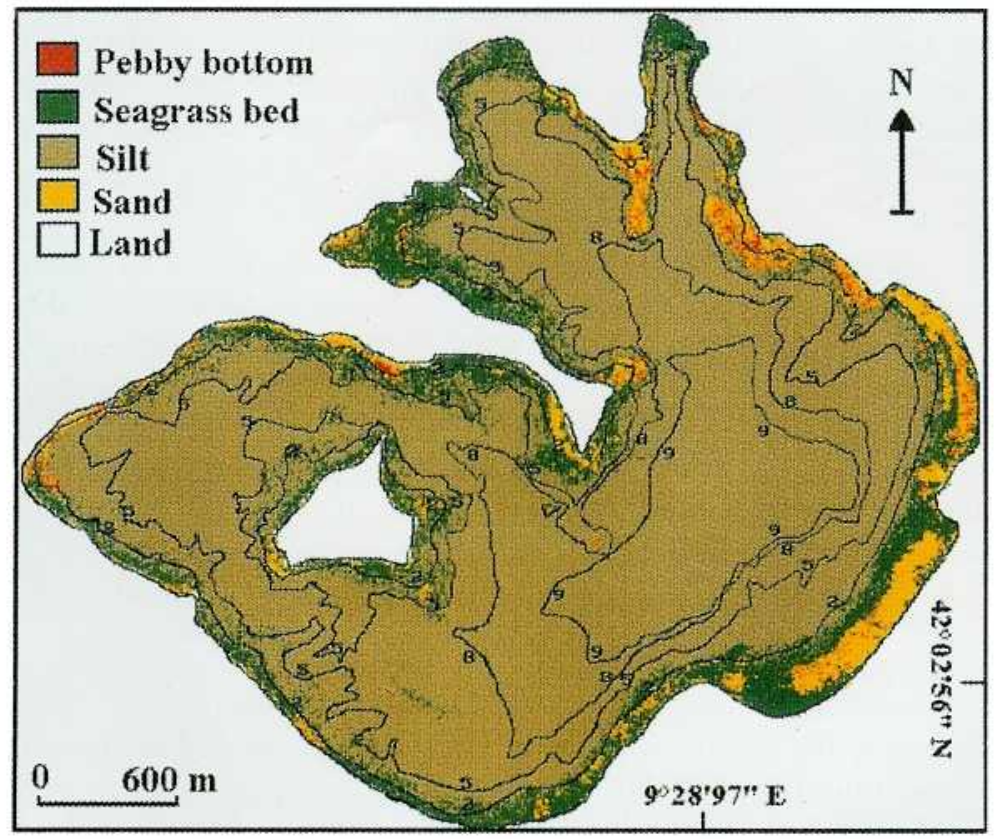

Figure 4. Map of the main benthic assemblages and bottom types of the Urbino lagoon. 
processing procedure. The reliability of the resulting map depends on the accuracy with which the polygons are positioned and their number, which may not always be realisable because of the size of the area investigated (table 1).

On the basis of these various parameters, it is possible to establish a map reliability scale, with each parameter taken separately and numbered from 0 to 3 points (table 1). While the reliability of a map can be enhanced by extending the scope of the investigation (more field data, more reference points, etc), it is impossible to alter the intrinsic characteristics of the site. Similarly, improvement of the aerial photographs or alteration of the geometrical rectification (e.g., distribution of reference points) would appear to be difficult to achieve. It seems therefore desirable to allocate a comparable importance to these two types of parameters in the scale of reliability, by using a weighting coefficient (table 1).

The map of the Posidonia oceanica reef formation in the Gulf of St. Florent (figure 3; Molinier and Picard 1952) is an example of a particularly accurate biocenosis map (pixel size $1 \mathrm{~m}$ ), which has led to the identification of a Posidonia oceanica micro-atoll with a diameter of about $10 \mathrm{~m}$. On the scale of reliability described above, the reliability of this map is estimated at 92 per cent (table 2). If one applies this scale of reliability to three other areas of the Corsican coast which exhibit different morphological characteristics (coastal lagoon, sandy coast, rocky coast), the reliability ranges from 62 to 76 per cent (table 2). However, there is a different explanation for the values of 76 per cent recorded both at the Urbino lagoon (figure 4) and the sandy stretch of the east coast (figure 2): the strong turbidity of the lagoon and the poor differentiation of the assemblages and bottom types are the main causes of the poorer reliability of this map. On the east coast, the drop in reliability is attributable to the distribution of reference points and to the greater depth range surveyed (table 2). Moreover the area covered by the field data survey represents less than 1 per cent of the whole area investigated because of the very diverse nature of the assemblages and bottom types. The poor reliability obtained at the Cap Corse site (figure 5) may be explained by a combination of several negative factors: the rugged and irregular topography, poor differentiation of assemblages and bottom types and a survey area that covers a very wide depth range.

\section{Conclusion}

Our first results demonstrate the potential of aerial teledetection associated with image processing for biocenosis cartography. Image processing by depth range represents a significant improvement in terms of differentiation between assemblages and bottom types with a wide bathymetric distribution range, such as the Posidonia oceanica seagrass beds.

Nevertheless, other factors that are intrinsic to the technique used and to the site studied may affect the quality of the results obtained. The identification and assessment of the impact of these various parameters provides the basis for a scale of reliability. By applying this scale to four areas of the Corsican coast, it has been possible:

(i) to assess the accuracy of the maps (62 to 92 per cent),

(ii) to identify the factors, which may vary from one site to another, that could detract from the reliability of the maps,

(iii) in some cases, to remedy at least partially this problem (e.g., by increasing the amount of field data). 
Table 2. Assessment of the map reliability for four sites of Corsica.

\begin{tabular}{|c|c|c|c|c|}
\hline \multirow[b]{2}{*}{ Factors } & \multirow[b]{2}{*}{$\begin{array}{l}\text { St Florent reef } \\
\text { formation }(2)\end{array}$} & \multicolumn{2}{|c|}{ Scale of reliability } & \multirow[b]{2}{*}{$\begin{array}{l}\text { Cap Corse } \\
(4)\end{array}$} \\
\hline & & $\begin{array}{l}\text { Urbino lagoon } \\
\text { (3) }\end{array}$ & $\begin{array}{l}\text { Mouth of the } \\
\text { Fium'Alto (1) }\end{array}$ & \\
\hline \multicolumn{5}{|l|}{ Survey site } \\
\hline Topography: slope & Slight and even (3) & Slight and even (3) & Slight and even (3) & Strong and uneven $(0)$ \\
\hline Bathymetric range & 0 to $10 \mathrm{~m}(2)$ & 0 to $10 \mathrm{~m}(2)$ & 0 to $20 \mathrm{~m}(1)$ & 0 to $20 \mathrm{~m}(1)$ \\
\hline $\begin{array}{l}\text { Water turbidity: visualization of assemblages } \\
\text { and bottom types }\end{array}$ & $\begin{array}{l}100 \% \text { of the depth } \\
\text { range studied (3) }\end{array}$ & $\begin{array}{l}\text { Less of } 50 \% \text { of the depth } \\
\text { range studied }(0)\end{array}$ & $\begin{array}{l}100 \% \text { of the depth } \\
\text { range studied (3) }\end{array}$ & $\begin{array}{l}100 \% \text { of the depth } \\
\text { range studied (3) }\end{array}$ \\
\hline Nature of assemblages and bottom types & Different (2) & Different (2) & Very different (3) & Similar (1) \\
\hline \multicolumn{5}{|l|}{ Aerial photography } \\
\hline Quality & Very good (3) & Very good (3) & Very good (3) & Very $\operatorname{good}(3)$ \\
\hline Surface effects: specular reflexion, wave plane & No surface effect (3) & No surface effect (3) & No surface effect (3) & No surface effect (3) \\
\hline $\begin{array}{l}\text { Scanning } \\
\text { Pixel size }\end{array}$ & Pixel $\leqslant 2$ m $(3)$ & Pixel $\leqslant 2$ m (3) & $2 \mathrm{~m}<$ Pixel $\leqslant 5 \mathrm{~m}(2)$ & $2 \mathrm{~m}<$ Pixel $\leqslant 5 \mathrm{~m}(2)$ \\
\hline \multicolumn{5}{|l|}{ Geometrical rectification } \\
\hline Reference points: number & Number $\geqslant 20(1.5)$ & Number $\geqslant 20(1.5)$ & Number $\geqslant 20(1.5)$ & Number $\geqslant 20(1.5)$ \\
\hline distribution & In 3 directions (1) & In 4 directions (1.5) & In 2 directions $(0.5)$ & In 3 directions (1) \\
\hline Referentiel scale/Image scale & Referentiel > image (3) & Referentiel $=$ image $(2)$ & Referentiel = image $(2)$ & Referentiel = image $(2)$ \\
\hline \multicolumn{5}{|l|}{ Field data } \\
\hline Area covered by field data/study site area & $\begin{array}{l}\text { Area } \geqslant 10 \% \text { of the } \\
\text { study site area }(3)\end{array}$ & $\begin{array}{l}5 \%>\text { Area } \geqslant 1 \% \text { of the } \\
\text { study site area }(1)\end{array}$ & $\begin{array}{l}\text { Area }<1 \% \text { of the } \\
\text { study site area }(0)\end{array}$ & $\begin{array}{l}\text { Area }<1 \% \text { of the } \\
\text { study site area }(0)\end{array}$ \\
\hline \multicolumn{5}{|l|}{ Classification } \\
\hline $\begin{array}{l}\text { Number of polygons by assemblages and } \\
\text { bottom types }\end{array}$ & Number $>30(3)$ & Number $>30(3)$ & Number $>30(3)$ & Number $>30(3)$ \\
\hline Percentages (\%) & 92 & 76 & 76 & 62 \\
\hline
\end{tabular}




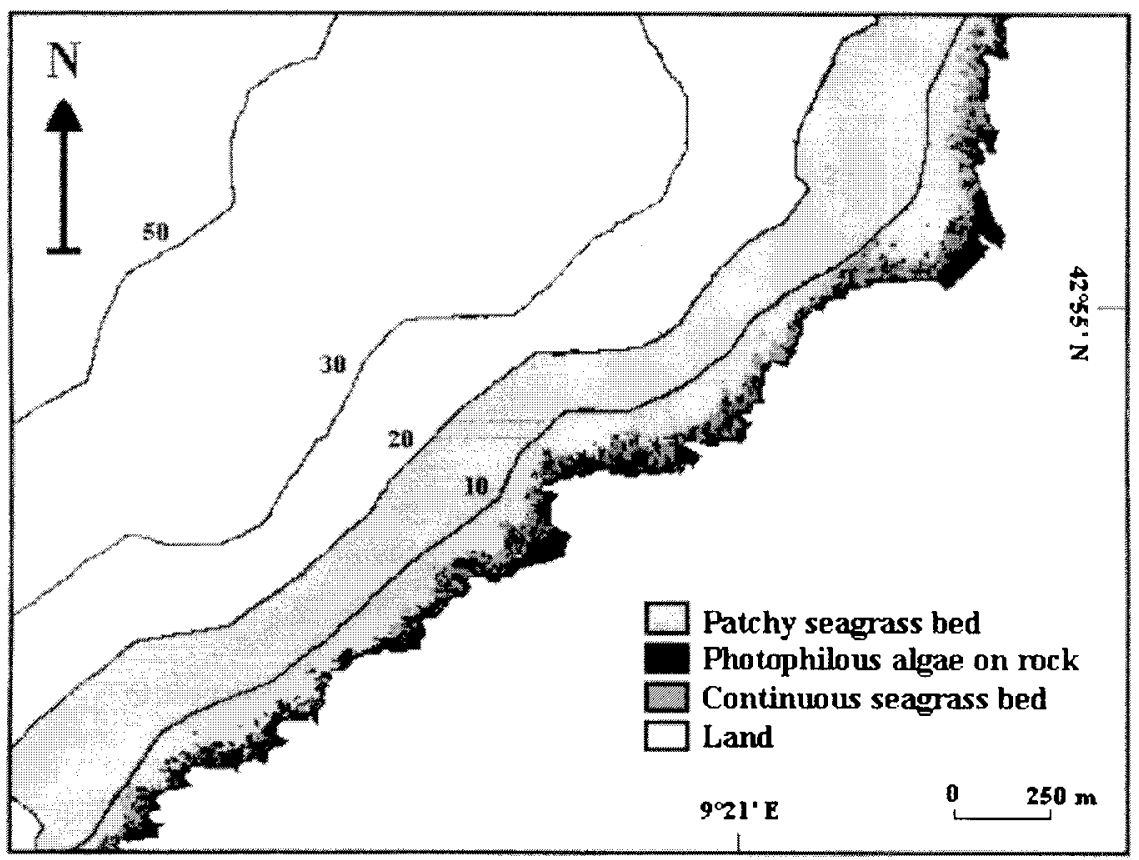

Figure 5. Map of the main benethic assemblages and bottom types in the vicinity of Cap Corse, between 0 to $20 \mathrm{~m}$ depth.

Nevertheless, while there is always the possibility of improving the accuracy and therefore the reliability of a given map, the necessity of matching the objectives in terms of budget-time cost must be borne in mind. The results obtained from three of the four sites studied displayed a superior reliability up to 75 per cent. While these values may appear to be low if the use of such maps for a resources management plan is envisaged, they may be quite acceptable as preliminary working documents for areas for which there is a complete absence of data.

Because of the general character of the criteria chosen here, this scale of reliability could well be applied to cartographical surveys of other assemblages or types of coastal sea bed (e.g., coral reefs).

\section{Acknowledgments}

This study has benefitted from European funding (Program INTERREG I and STRIDE), and could not have been carried out without the assistance of GIS-Posidonie - Centre de Corse and the Direction Régionale de l'Environnement de Corse. We thank the reviewers for their constructive criticisms that have enabled us to make notable improvements to the article.

\section{References}

Belsher, T., Meinesz, A., Lefevre, J. R., and Boudouresque, C. F., 1988, Simulation of Spot satellite imagery for charting shallow water benthic communities in the Mediterranean. Marine Ecology, 9, 157-165. 
Courboules, J., and Manière, R., 1992, Apport de la télédetection à l'étude de la relation entre l'hydrodynamisme de surface et les récifs coralliens. International Journal of Remote Sensing, 13, 1911-2923.

Courboules, J., Manière, R., and Bouchon, C., 1988, Systèmes d’informations géocodées et télédétection à haute résolution. Exemple d'application aux côtes jordaniennes. Oceanologica acta., 11, 337-351.

Fergusson, R. F., Wood, L. L., and Graham, D. B., 1993, Monitoring spatial change in seagrass habitat with aerial photography. Photogrammetric Engineering \& Remote Sensing, 59, 1033-1038.

Kelly, M. G., 1980, Remote sensing of seagrass beds. In Handbook of Seagrass Biology: An Ecosystem Perspective, edited by R. C. Phillips and C. P. McRoy (New York: Garland STPM Press), pp. 69-86.

Kerdoun, A., 1992, Stratégie de développement et protection de l'environnement en Méditerranée. Suds et Iles méditerranéennes: Terres d'initiatives ou terres d'assistance?, Symposium held in Ajaccio, France, on 29-31 October 1992 (Corte: Editions Universitaire de Corse), pp. 399-405.

Kirkman, H., 1990, Seagrass distribution and mapping. In Seagrass research methods, edited by R. C. Phillips and C. P. McRoy (Paris: Unesco Press), pp. 19-26.

Lefevre, J. R., Valerio, C., and Meinesz, A., 1984, Optimisation de la technique de la photographie aérienne pour la cartographie des herbiers de Posidonies. In International Workshop Posidonia oceanica Beds, edited by C. F. Boudouresque, A. Jeudy de Grissac, and J. Olivier (Marseille: GIS Posidonie press), 1, pp. 49-55.

MANIĖRE, R., and JAUBERT, J., 1985, Traitements d'image et cartographie de récifs coralliens en Mer Rouge (Golfe d'Aqaba). Oceanologica Acta, 8, 321-330.

Manière, R., Bouchon, C., and Bouchon-Navaro, Y., 1994, Mapping of the seagrass beds in the bay of Fort-de-France (Martinique, French West Indies) by digitized aerial photographies. Proceedings of the First International Airborne Remote Sensing Conference and Exhibition, Strasbourg, France, 11-15 September 1994, pp. 735-743.

Meaille, R., Wald, L., and Boudouresque, C. F., 1988, Cartes des peuplements benthiques en Méditerranée: constitution d'une banque de données géocodées et synthèse cartographique. Oceanologica Acta, 11, 201-211.

Meinesz, A., Astier, J. M., and Lefevre, J. R., 1981, Impact de l'amènagement du domaine maritime sur l'étage infralittoral du Var, France (Méditerranée occidentale). Annales de l'Institut Océanographique, 57, 65-77.

Meinesz, A., Boudouresque, C. F., and Lefevre, J. R., 1988, A map of the Posidonia oceanica beds of Marina d'Elbu (Corsica, Mediterranean). Marine Ecology, 9, 243-252.

Meinesz, A., Belsher, T., Boudouresque, C. F., and Lefevre, J. R., 1991, Première évaluation despotentialités du satellite SPOT pour la cartographie despeuplements benthiques superficiels de Méditerranée Occidentale. Oceanologica Acta, 14, 299-307.

Molinier, R., and PiCARD, J., 1952, Recherches sur les herbiers de Phanérogames marines du littoral méditerranéen français. Annales de l'Institut Océanographique, 27, 157-234.

Morgan, K. M., Newland, L. W., Weber, E., and Bussey, A. B., 1993, Using Spot satellite data to map impervious cover for urban runoff predictions. Toxicological and Environmental Chemistry, 40, 11-16.

Pergent, G., Chessa, L., Cossu, A, Gazale, V., Pasqualini, V., and Pergent-Martini, C., 1995. Aménagement du littoral: Apport de la cartographie benthique. ResMéditerranea, 2, 45-57.

Philipeau, G., 1992, Comment interpréter les résultats d'une analyse en composantes principales? (Paris-STAT-ITCF).

Pirazzoli, P. A., 1982, Télédetection en milieu récifal, utilisation d'une image Landsat pour évaluer la bathymétrie dans l'atoll de Rangiroa (Polynésie Française). Océanis, 8, 297-308.

WALKer, D. I., 1989, Methods for monitoring seagrass habitat. Report of a workshop, Melbourne, 20-22 June 1988, Perth, VIMS Working Paper, Perth, 18, 1-26 + Ann. 